\title{
Disquieting uncertainty. Three glimpses into the future
}

\author{
Volker H. Schmidt ${ }^{1}$ \\ Received: 14 June 2017 / Accepted: 29 August 2017 /Published online: 30 September 2017 \\ (C) The Author(s) 2017. This article is an open access publication
}

\begin{abstract}
The article sketches three major realms - the realm of world order, the realm of work, and the realm of social policy - that will in all likelihood undergo fundamental change in the years and decades ahead, raising deeply unsettling questions about their future. The account is framed by the concept of global modernity, which, while not spelled out in detail, guides the presentation of data and other secondary materials in the aim to demonstrate connections between, and, at least to some extent, common roots of, phenomena and developments that might otherwise appear to be quite disparate. The author does not present any solutions for the problems and challenges discussed in the article, but hopes to sensitize readers to their urgency and to stimulate fruitful ideas for what will ultimately have to be a collective endeavor involving not only scholars from around the world but also the general public.
\end{abstract}

Keywords Global modernity · Radical change $\cdot$ World order · Work · Social policy

"[T] he idea of the future being different from the present is so repugnant to our conventional modes of thought and behavior that we, most of us, offer a great resistance to acting on it in practice"

John Maynard Keynes, 1937

Volker H. Schmidt

socvhs@nus.edu.sg

1 Department of Sociology, National University of Singapore, 11 Arts Link, 117570 Singapore, Singapore

\section{Introduction $^{1}$}

In what follows, I outline three broad areas - the realm of world order, the realm of work, and the realm of social policy - that will in all likelihood undergo fundamental change in the years ahead, raising deeply unsettling questions about their future. Each of these areas can and should be analyzed separately as they pose distinct problems and challenges, but they are also interconnected, making it useful to investigate them within a common frame of reference. The framework that I propose for this purpose is the concept of global modernity, presented in a recent book [81]. This concept bundles and systematizes, at a relatively high level of abstraction, changes that have been observed separately in much of the pertinent literature, including the literature on globalization, within an integrated scheme that aims to sensitize social scientists to their complexity, multidimensionality, and, indeed, interrelatedness. $^{2}$

\footnotetext{
${ }^{1}$ The author gratefully acknowledges helpful criticism and suggestions he received from two anonymous reviewers.

2 The phrase "global modernity" is not new, but mostly used in a loose, unsystematic fashion. My own conceptualization is rooted in Talcott Parsons' distinction between the social system, the cultural system, the personality system, and the organismic system (or behavioral organism). Drawing on this scheme yields a four-dimensional concept of change, with modernization processes involving fundamental transformations in each dimension and all of them being interrelated. The scheme's purpose is to sketch an analytic framework that demarcates the range of phenomena that must be minimally taken into account if we are to arrive at a meaningful understanding of (global) modernity. Its ability to capture modernity's complexity is arguably unmatched by any of the alternatives currently on offer in the social science literature. Therein lies its heuristic value, which I cannot even begin to demonstrate here because that would require much more space than a short article offers. The same applies to the account that follows. The trends and data reported are of course not new. But the way they are framed and presented is, hopefully shedding a different light on known facts and raising awareness for connections and implications that would remain invisible if treated in isolation, as they typically are in the original sources.
} 
For the sake of brevity, I do not provide much detail but confine myself to discussing some of the reasons suggesting why the issues in question are important. The concept of global modernity engenders the expectation of radical change in virtually all aspects of life, so the topics selected here for closer examination far from exhaust its analytic potential. One further subject deserving particular attention from the perspective of a theory of global modernity is the emerging biotechnological revolution, ${ }^{3}$ which has the potential to shatter the very foundations of humanity's self-understanding with wide-ranging implications not least for the social sciences. That however, is not my current concern.

\section{The future of world order}

The past four decades or so have seen what arguably amounts to the greatest and most dramatic transformation in human history. During this phase, various critical thresholds have been surpassed as a result of which many of the hallmarks of modern development for the first time reached genuinely global proportions, shaping the lives of people around the world and turning what until then had been a minority phenomenon into a lived reality for the majority of the human population [77]. I call this the condition of global modernity.

The breakthrough of global modernity is an event of seismic proportions whose significance we are only just beginning to understand. It affects all spheres of life and all institutional sectors of society. Here, I focus on the economy. The world of today is rich beyond the imagination of even the most farsighted nineteenth century observers, and much of this wealth is the product of modern economic growth, widely believed to have taken off around 1820 [56]. Following this take-off, the value of the world's GDP increased by the equivalent of 22 trillion US\$ until 1985. Nothing like this had ever happened before. But as spectacular as it must have appeared to any historically conscious contemporary, by today's standards this "economic miracle" is in fact quite unimpressive. For as early as 2010 , just 25 years later, global GDP had risen by another 30 trillion dollars [28]. So the value added in a single quarter century is substantially greater than the combined total of the 150 years preceding it.

Spatially, much of the recent growth is concentrated in Asia, especially in East Asia. Thus, while per capita incomes

\footnotetext{
3 Two other problems strongly affected by the developments which have given rise to the breakthrough of global modernity are climate change and ecological degradation - simply because this breakthrough dramatically amplifies the factors driving them (for a few hints, see [78]). Here, I nonetheless bracket them out because awareness of their actual and potential consequences is already quite widespread, whereas reflection on the problems addressed in the present article is only just beginning. That does not make these latter problems any more important. But they certainly add to the difficulties facing humanity in the early stages of this century, and they may well turn out to be equally urgent. Hence the need to attend to them as well.
}

grew by $62 \%$ in the United States and $74 \%$ in the United Kingdom between 1980 and 2009, these rates, remarkable as they are, pale in comparison to those exhibited by India (+ $230 \%)$, South Korea $(+360 \%)$, the Asia-Pacific region (+ $594 \%$ ) and China (+ 1.083\%) [28: 9]. When interregional performance varies considerably over longer periods of time, then this changes the relative weight of regions in the world. The perhaps most consequential shift of this type in modern economic history was the rise of, first, Europe, then the West following (what is now often called the First) Industrial Revolution. Currently, we are in the midst of an equally consequential shift, this time from West to East. Calculated in purchasing power parity (PPP) terms, the EU28's share of global GDP was roughly $31 \%$ in 1980 , while that of the United States stood at $25 \%$ according to the IMF. At the same time, China's GDP accounted for as little as $2.2 \%$. By the year 2012, the EU's share was down to $19.2 \%$, that of the US to $19.5 \%,{ }^{4}$ while China's had risen to roughly $15 \% .{ }^{5}$ Looking at Asia as a whole, the continent's share of global GDP increased from less than one quarter (23.2\%) in 1990 to $38.8 \% 25$ years later (2014), just surpassing the combined output of the EU and the US in 2012 (38.7\%). These trends have since continued. By 2020, the joint economic product of the EU and the US is expected to have declined to approximately $30 \%$ of world GDP, while that of China alone should have risen to as much as $19 \%$. Five years later, in 2025, Asia is projected to account for $45 \%$ of global GDP and to be home to by far the largest fraction of the world's middle class [14, 50].

Similar shifts are taking place in education (or human capital formation; see below); science and technology (or R\&D) and, last not least, military spending/build-up/capacity. ${ }^{7}$ Taken together, their impact is huge, representing nothing less than a world-historical turning point. They bring to a close several centuries of Western global dominance and supremacy, giving rise to an increasingly polycentric world wherein the West ceases to be the single most important driver, model and beneficiary of modernization and is reduced to one of several players, no longer able to determine the rules of the game and the parameters of change for all.

The erosion of the westcentric world order is a gradual process, so it took a while before it received widespread

\footnotetext{
${ }^{4}$ In market exchange rate terms, the EU's share was $23.7 \%$ in 2012, that of the US 22.2\%; see Eurostat 2015, The EU in the World - Economy and Finance. http://ec.europa.eu/eurostat/statistics-explained/index.php/The_EU_in_the world_-_economy_and finance. Accessed 21 August 2017.

While the figures vary with the methods of calculation chosen, the magnitude of the observed change is roughly the same.

${ }^{5}$ See Global Vision (2013) EU-28 is no Longer the World's Largest Economy. http://www.global-vision.net/blogging-brussels-beyond/eu-28-is-no-longerthe-worlds-largest-economy. Accessed 21 August 2017.

${ }^{6}$ Indeed, even the centers of innovation - and hence of technological change are beginning to shift away from the West. For instance, a report of the European Commission [29] estimates that China's innovation potential had increased to almost half the EU level by 2015, up from 35\% in 2006 .

${ }^{7}$ On military spending, see [70].
} 
attention. However, since about the second half of the last decade, its inevitability became apparent to a growing number of analysts (see, e.g., [53]), coupled with the understanding that this will change the opportunity structure of economic and political actors around the world. What exactly the shape of a future world order will look like is unclear, but leading players expect the changes to be profound. For instance, in its Global Trends 2025 report the United States' National Council of Intelligence [62: vi] predicts that "the international system as constructed following the Second World War - will be almost unrecognizable by $2025^{\prime \prime}{ }^{8}$ Existing institutions of global governance (such as the United Nations Security Council, the IMF, the World Bank, the World Trade Organization) face growing pressure to adapt to the new realities and have seen the emergence of new institutions (such as the Asian Infrastructure Investment Bank) which partly complement, partly compete with them. Others have morphed into larger, more inclusive bodies to accommodate new players (e.g., the transmutation of the G7/8 into the G20 in the wake of the latest global financial crisis). Under the Obama administration, the United States was "pivoting" toward the AsiaPacific, partly raising, partly defusing tension by keeping aspiring regional hegemons (mainly China) in check, while also, by moderately retreating from other regions, creating power vacuums that opportunistic players were quick to step into (cf. the examples of the Middle East; Ukraine). Under the new Trump administration, the US appears to resort to growing isolationism and unilateralism, withdrawing from prior political, trade and environmental commitments (cutting UN funding; pulling out of TPP in the Asia-Pacific and out of the Paris climate agreement), toying with economic protectionism, and putting in doubt long-standing military alignments (such as NATO). The aggregate effect may well be that the country unwittingly vacates the global leadership role it had enjoyed for decades. For this opens the door for others to fill its place (as donors and sponsors of multilateral organizations; as trade partners; as security providers) and/or induces them to reconsider their interests, positions and strategic options. Regional blocks such as the EU or ASEAN are struggling to counter the declining power of (smaller) nation states but face growing difficulties of internal cohesion and unitary policy-making. ${ }^{9}$ Meanwhile, limited statehood in world regions lacking "domestic sovereignty" [52, 74] offers niches

\footnotetext{
${ }^{8}$ According to Acharya [1], this order is already over or at least irrevocably dissolving. That it will not necessarily give way to an "Asian" order (as suggested by the "Asian Century" hype) is noted by scholars who take ongoing transformations seriously without being overhwelmed by them (see, e.g., [95]). Nonetheless, few observers doubt that Asia, particularly China, will play a central role in the shaping of any future order.

9 The resurgence of aggressive ethno nationalism/right-wing populism, the immigration crisis, and "Brexit" are only the most visible symptoms of these difficulties in Europe. ASEAN also shows signs of growing or at least continuing fragmentation, despite long-standing formal commitments to greater integration (see [41]).
}

for newly (educationally, technologically, etc.) empowered non-state actors who are becoming progressively able to perpetrate large-scale "informal" violence [45] within and beyond the borders of their countries of residence. Concurrently, the mediatization of politics [37], intensified by the digital revolution, expands the repertoire of statecraft, while at the same time multiplying and amplifying the voices engaged in international relations, thus partly supplementing, partly subverting, and partly substituting conventional diplomacy, which alters the entire foreign policy landscape (see, e.g. $[68,96])$. All of this gives rise to geopolitical uncertainty and increases the volatility of existing arrangements.

Less visible than these and other developments are movements away from political oversight and control that are taking place within important institutional sectors of (world) society and that have been likened to processes of self -"constitutionalization". The economy, the law, science, health, medicine and even education have all established increasingly autonomous governance systems in recent decades that follow a sectoral logic of domain-specific regulation rather than a political logic of territorial segmentation and subordination to a national agenda [88]. As has been noted repeatedly in the literature on economic globalization [76, 83], this development was to some extent sanctioned, if not initiated, by the political system itself. Yet, over time it spawned a distinct type and layer of order that increasingly defies political control (see [27, 86]) and/ or turns what used to be seen as the central agents of policymaking into policy takers [12] whose "scripts" for action (in such fields as norm making, agenda-setting, even policy formulation and implementation) are crafted by a diffuse but authoritative "world polity" [60] comprising global ("world" rather than "international"; see [49]) governance organizations, law courts, corporations and business associations, NGOs, think tanks, advocacy networks, professional associations, expert epistemic communities, social movements, and others (see, e.g., $[10,17,24,38])$. In short, many of the policies perceived and portrayed by national governments as resulting from their sovereign right to govern without interference from the outside must in fact be viewed as being exogenously driven, a condition that applies even to the most powerful states.

How the various forces and actors that are engaged in these processes and that have a stake in their outcomes interact, coalesce, and subvert each other in the making and remaking of global (dis-)order is not well understood. They do, however, have a significant impact on the possibility space for purposive (political) action aiming to shape and possibly improve the life chances of global citizens.

\section{The future of work}

The disruptive changes that are underway at the level of world order are matched by equally disruptive changes in the way 
we live, work, and relate to one another following recently accomplished technological breakthroughs in artificial intelligence, robotics, the internet of things, big data gathering and processing, 3D printing and other fields that are ushering in what has been variously labelled a "Second Machine Age" [19], a "Fourth Industrial Revolution" [84] or simply "Industry 4.0". The partly very upbeat literature is full of praise for the expected benefits and opportunities this promises for aggregate wealth creation and economic growth, but also warns against underestimating associated risks and downsides which it says require careful management to prevent major social problems.

Two interrelated problems stand out: first, emerging technologies' job automation potential; and second, growing labor market polarization deepening already high levels of social inequality that have grown continually during three and a half decades of globalization, market liberalization, and welfare state retrenchment. ${ }^{10}$ According to one influential study [33], about $47 \%$ of the workforce in advanced economies are at a "high risk" of technological substitution over the course of the next two decades. ${ }^{11}$ And while in the past the targets for automation were heavily concentrated in the lowskilled segments of the labor market, today sizable fractions of higher level skills and even professional occupations are becoming susceptible too, as general purpose technologies equipped with "synthetic intellect" [42] can perform increasingly complex tasks. Thus, it is estimated that worldwide, up to 100 million knowledge workers [51] in fields as diverse as the law, medicine, the mass media, finance, education, and even science could be replaced by sophisticated computer algorithms that (will soon have the capacity to) outperform humans in a wide range of cognitive tasks long believed to be the latters' preserve. The innovations on which these advances depend are progressing at an exponential rate, taking even insiders by surprise. For instance, as late as 2004, leading computer specialists thought self-driving cars would not become a reality for decades to come. Yet, just six years later,

\footnotetext{
${ }^{10}$ Welfare state retrenchment is largely a phenomenon of the Western and the former Socialist worlds. The trends in other regions, albeit starting from a low base, have pointed toward expansion, not retrenchment, of statutory welfare systems (see, e.g., [36, 54]).

${ }^{11}$ In the developing world, an even higher share (of up to two thirds) of the working-age population could be affected (see [21, 96:126ff.]), partly because its economic development relies heavily on manufacturing, and manufacturing jobs are highly susceptible to automation. Robotic automation is also making substantial inroads into agriculture, another important source of employment in the developing work. Where it does not directly eliminate jobs, it helps keep wages down. This problem is potentially exacerbated by the emerging trend of "re-shoring" manufacturing to the developed world (see, e.g., [67, 85]) because in some industries technological progress is reducing the need for human labor so drastically that cheap labor in the developing world no longer offers a significant competitive advantage. At the same time, automation is beginning to target many back office service and IT functions that had earlier been offshored to low labor cost locations such as the Philippines, India, Brazil or Poland. These jobs will not be re-shored but rather "no-shored" ([69: ch. 6]; see also [16]), i.e. evaporate - into the cloud(s) or into obsolescence.
}

Google revealed that its autonomous car had been driving successfully for some time, and business reports now suggest such cars could go into mass production as early as 2020 . Foreshadowing this development, in August 2016 the first driverless taxis were put on the road in Singapore, and the operators are planning to make the service commercially available by 2018 ; similar trials have since started elsewhere [87].

These trials mark the beginnings of the end of driving jobs. Other jobs will likewise begin to disappear soon or have already started disappearing (retail cashiers, baristas, news reporters, stock market brokers, laboratory research assistants, radiologists, etc.). Optimists suggest the net job effect of emerging technologies may actually be positive, as eliminated jobs could be more than compensated for by new, safer and better paying ones requiring higher level skills. Others are more skeptical, arguing higher pay levels increase the incentives to substitute technology for labor and pointing out that the fast growing number of computer engineers is employed for precisely this purpose. ${ }^{12}$ And still others find the estimates of job displacement due to automation grossly inflated, noting that occupations usually combine multiple tasks only some of which can be shifted over to technology [8]. Using a taskbased approach, these researchers believe less than $10 \%$ of currently existing jobs are automatable in the OECD world, rather than almost half as predicted by Frey and Osborne. ${ }^{13}$ But be this as it may, there can be little doubt that the nature of work across virtually all occupations and professions is changing drastically, requiring new skills and capabilities whose acquisition will be a must for adequate task performance, but may prove too demanding for many current employees who simply cannot be retrained and have their skills upgraded to the needed levels. The consequences could be massive social dislocations and exclusion on a wholly new scale. ${ }^{14}$

A second negative consequence expected to result from the evolving automation wave is a growing segregation of the labor market into a relatively small high-skill/high-pay segment and a much bigger low-skill/low-pay segment due to a hollowing-out of mid-level skill/middle income jobs -

\footnotetext{
12 See especially Ford [32], who also notes that part of the work these engineers do is ultimately destined to make themselves redundant.

13 See also PWC (Price Waterhouse Coopers)2017, UK Economic Outlook, March 2017, http:/www.pwc.co.uk/services/economics-policy/insights/ukeconomic-outlook.html. Accessed 21 August 2017,

which draws on the research of both Frey and Osborne [33, 34] and Arntz et al. [8] and focuses on the UK. This study estimates the job automation potential over the next 15 years to range between $21 \%$ in Japan and 38\% in the USA. McKinsey Global Institute research suggests that $60 \%$ of all existing jobs have at least $30 \%$ of activities that are automatable with currently available technologies, thus both reducing the overall need for labor and meaning that more people will have to work with advanced technology. Globally, as many as 1.2 billion workers could be affected by this development, see [58].

${ }^{14}$ In the developing world, this could reverse the vast reductions of extreme poverty accomplished during the past two decades - which, if it happened, might well increase the immigration pressure on the developed world.
} 
a trend that began at least two decades ago but is likely to be accelerated in the near future [9]. Moreover, as automation, while hurting some categories of workers more than others, substitutes for labor across the economy, it exacerbates the gap between returns on capital and labor, widely assumed to be one of the primary drivers of rising income inequality (see, e.g., [61, 71]), because it exerts downward pressure on wages despite gains in worker productivity. At the same time, advances in computer-driven technology reduce the relative costs of investment goods, leading firms to replace workers by machinery and, according to some estimates, accounting for as much as half of labor's recent decline in the share of GDP [34: 7] Thus, while innovators, shareholders and investors benefit substantially, the lower middle and/or working classes in economically advanced countries find themselves in an increasingly tenuous position, adding to their already mounting frustration caused by income stagnation, relative deprivation, anxiety, sometimes even downright impoverishment, and serving as a catalyst for social unrest and conflict. ${ }^{15}$ In the developing world, on the other hand, automation could prematurely end or at least decelerate the emergence of an income stratum whose growing prosperity led several observers to predict the rise of a genuinely global middle class for the first time in modern history (see, e.g., [47]).

While addressing these problems may be urgent, it is also difficult. In contrast to previous technological transformations, the current, ICT-enabled "industrial" revolution is characterized not only by fast-paced technological change, but also by much lowered barriers to knowledge diffusion and appropriation, thus decoupling innovation/production from fixed territorial spaces (essentially the nations of the Global North) and anchoring competitiveness in unbounded, globally spread production networks [22] that form the central nodes of continuously expanded supply chains [46]. Moreover, its effects are less concentrated in particular business sectors or workforce segments but exhibit a "finer degree of resolution" [11: 169], making competition more individual. At the same time, the constant acceleration of computing speed in conjunction with the synergies created by the simultaneous development of seemingly disparate but often surprisingly

\footnotetext{
15 One of the consequences of the decline of labor's share in aggregate incomes (a trend observed globally; see [43]) is the growing number of working poor. A study on fast-food workers in the USA (see [4]) found that more than half of their families were enrolled in public assistance programs without which they could not make ends meet. Another consequence is that many of today's young adults in the developed world are materially (much) worse off than their parents' generation was at the same age stage despite substantial gains in educational attainment and skill formation [26]. The growing discontent with political democracy and the rising support for authoritarianism in the younger age-cohort (see [31]) may be partly rooted in this development. In the United States in particular, lawmakers' low responsiveness (see [35: ch. 8]) to the concerns of what Piketty [71: 297] sardonically calls the "bottom 90\%" of the population could further contribute to this discontent.
}

complementary technologies permits inroads into realms long thought to be immune to technological substitution. Impacts are therefore more sudden, more unpredictable, and more uncontrollable than in the past, defying much of the twentieth century policy toolkit and presenting unprecedented challenges for individual and collective actors alike. Policymaking depends on expectations about the future, but when no reliable indicators exist for determining which fields and occupations will be affected next, then it resembles poking in the dark.

\section{The future of social security}

The future of work is an important issue not only in its own right, but also in relation to the provision of social security. One of the guiding assumptions underlying the institutional design of the welfare state is that the "normal" way through which the majority of the population secures its livelihood is gainful employment in the private or public sector. This "productivist syndrome" [66], which, if to varying degrees, shapes and structures social policy regimes around the world ${ }^{16}$ evidently comes under stress when large numbers of perfectly capable adults find themselves unemployable or employable only under permanently precarious conditions when, indeed, structural unemployment, economic redundancy, high job insecurity/turnover, low wages, etc., become the new normal.

The literature on the future of work may even underestimate this problem because it strongly focuses on technological factors while bracketing out large-scale social transformations that arguably complement the former in setting the stage for further, quite possibly even more radical change. Technologies themselves no doubt help speed up technological innovation because the latest technologies constitute important building blocks for new, next-generation technologies. Yet, their innovation potential grows substantially when combining cutting-edge technologies with qualified "human resources" and "suitable", innovation-prone institutions. In both respects, tectonic changes have taken place in recent decades.

Beginning with the former, the world's human capital and knowledge stocks have grown exponentially since the 1960s onset of what Schwab [84] calls the Third Industrial Revolution. In 1960, there were about 150 million adults around the world who had completed secondary education, 80 million of whom lived in the developed world. By 2010, there were 1.24 billion, 940 million of whom are from developing countries [13]. Tertiary education shows an even

\footnotetext{
${ }^{16}$ Probably most strongly in East Asia, where social protection has generally been subordinated to economic growth policies orchestrated by strong developmental state apparatuses (see [39, 48]).
} 
steeper increase. Between 1970 and 2000, the number of students enrolled in higher education organizations worldwide more than tripled from 28.6 million to 100.8 million [89]. A mere decade later, by 2011, it had surged to 182 million [90], with most of the growth coming from Asia and the upward trend showing no signs of abating. No less momentous is the expansion of science. Following several centuries of exponential growth [72], global science reached an inflection point after which the numbers became staggeringly high. Thus, approximately 360,000 science and engineering articles were published annually by 1985 . Then, in a matter of less than two decades, that figure skyrocketed to 1.1 million per year in 2003. Just 10 years later, in 2014, it had reached almost 2.2 million (see the chart in World Bank ${ }^{17}$ ), and at its current growth rate of $7-9 \%[18,63]$ will double to 4.5 million in another decade. The trends in patenting exhibit a similar trajectory. In both cases, the main driving force is the recent massive build-up of research capacities in (East) Asia [40, 91].

A second major social transformation is the world's transition toward a predominantly capitalist economy beginning with the introduction of market reforms in China around the turn to the 1980s. As late as 1965, only the West, Japan and the four East Asian "tigers", together representing no more than $21 \%$ of the world's population, were "genuinely capitalist in orientation" [75: $28 \mathrm{f}$.]. Today, the vast majority of humankind lives under capitalist institutions or in countries moving toward their introduction and consolidation, a complete reversal of the situation just a few decades ago. This expansion has not only brought capitalism's dynamism to a wholly new lev$\mathrm{el}$, it also spurred unprecedented competition, adding millions of new businesses ${ }^{18}$ and hundreds of millions of new workers to global product and labor markets, whose integration is further facilitated by the growing ease of physical and nowadays also "virtual" migration (or, for that matter, virtual outsourcing/offshoring), enabled by the digital revolution [7]. ${ }^{19}$

This confluence of factors: (1) massively enhanced technological capabilities; (2) massively enhanced human capital and knowledge stocks; and (3) a massively expanded

\footnotetext{
${ }^{17}$ World Bank (n.d.) Science and Technical Journal Articles. 24 March 2017, http://data.worldbank.org/indicator/IP.JRN.ARTC.SC. Accessed 21 August 2017.

18 Among them are almost 100,000 transnational corporations [25: 20], a rapidly growing number of which are headquartered in India and China [92].

${ }^{19}$ The digital revolution, starting around the 1990s in the developed world, became a truly global phenomenon only around or after the millennium. About 1 billion people worldwide had access to the Internet in 2005. By mid-2016, this number had almost quadrupled to 3.7 billion users (see, Internet World Stats 2016, "Internet Users in the World by Regions, June 2016", http://www. internetworldstats.com/stats.htm). This means the virtual market place (for goods and labor) now reaches over half the world's population. Not surprisingly, online markets for contract labor are mushrooming, with employers in high-income countries hiring labor in low-income countries being the norm (see [3]).
}

capitalist (world) economy, combines in unleashing "productive forces" and in creating transformation potentials unlike anything seen before. How exactly this will play out in the arena of work is of course unknown. But given what we do know, it is far from unrealistic to visualize a scenario wherein jobless or even negative job growth becomes an enduring phenomenon because what we are witnessing today are only the early stages of a permanent revolutionizing of (productivity boosting, labor-saving) technologies. The pressures are on, and the means are (becoming) available.

In such a scenario social security would have to be progressively decoupled from paid work, as advocates of a universal basic income have argued for some time. If growing fractions of (what used to be) the workforce become unemployable through no fault of their own, and/or find themselves subject to the volatility and insecurity of "alternative work arrangements" [44] in the fast-evolving contracted-out economy, ${ }^{20}$ then the normative basis for tying eligibility for welfare benefits to life-long formal employment and for dividing the citizenry into "deserving" and "undeserving" categories of claimants loses much of its credibility. Given the limited scope for raising taxes in a globalized economy, it also means that new sources of revenue for funding transfers and services have to be found. One such source that might be worth exploring and that is being utilized successfully in countries as different as Norway and Singapore are sovereign wealth funds which combine the strengths of capitalist enterprise with "social" ownership, allowing them to pursue a long-term, relatively low risk investment strategy and to contribute to the state's budget by paying regular dividends. ${ }^{21}$

The need to reconfigure the welfare state derives not only from changes in the field of work, but also from various other challenges facing existing arrangements for the provision of social security. Of these, population ageing is one of the most widely discussed factors. Once again, the assumptions guiding these discussions may turn out to be too conservative - as in fact they often have been in the past [93]. When the first social insurance schemes where introduced in the late nineteenth century, life expectancy at birth was roughly half of what it is today. In the twentyfirst century, with steady progress made in genetic engineering, nanotechnology and related fields of biotechnological enhancement such as age-defying drug development, it is likely to increase further, perhaps substantially (see, e.g., [30, 59]). This would have major implications

\footnotetext{
${ }^{20}$ This includes (and is accelerated by) the newly emerging on-demand or "gig economy", which selectively utilizes discrete tasks performed/ competencies possessed by specialist workers offering their services in a world-wide "human cloud" (see [2 64]).

${ }^{21}$ For a survey of existing funds, see [5].
} 
for the future of social security, ${ }^{22}$ and it may well make sense to think ahead to be prepared, even if serious research undertaken with the aim of pushing the boundaries of longevity, until recently consigned to the realm of science fiction (just like many of the ideas driving robotics and artificial intelligence research had been until they began to become reality), is still in its infancy.

A third aspect of social policy reform worth looking into is the relative weight accorded different pillars of the welfare state, especially public education and the financing of medical care. Research suggests that greater welfare, including a higher health dividend, could accrue from shifting some of the resources currently devoted to funding largely ineffectual bio-medical treatment into the often underfunded educational system [55]. ${ }^{23}$ Likewise, if one's goal were to promote health justice in the face of mounting health inequalities, it would seem advisable to focus on strengthening public health measures and institutions rather than the medical system [23, 82, 94].

Finally, and perhaps most difficult to accomplish, the horizon for the projection of social policy reform must be expanded. In keeping with the conventions of methodological nationalism, many theories of justice, and hence also the social policy proposals inspired by them, delimit the scope of justice by the boundaries of the nation state. In a globalized world, this limitation loses much of its force. If, as Rawls [73] has persuasively argued, principles of justice are to regulate the most important institutions of society, and if society itself has gone global (with worldwide interdependencies intervening into all aspects of life and a constantly growing body of institutions put in place that affects all of humanity), then so must justice $[15,80]$. The central mechanism for dispensing social justice in the twentieth century was the national welfare state. But the realities of world society have surpassed it. And once these realities are acknowledged, certain habits of thought become untenable. The idea of a universal basic income is a case in point. For how universal can a policy be that limits its applicability to one or more particular ("imagined" and "caged", $[6,57])$ communities - as any policy that thinks in national terms must do? If, on the other hand, a truly

\footnotetext{
${ }^{22}$ The OECD [65: ch. 7] forecasts the remaining life expectancy of women aged 65 years to increase from today's average 20.8 to 25.8 years in 2060 . This alone would double aggregate expenses on pensions and medical care for the elderly. The prediction is based on a projection of current trends of longevity extension into the future. It does not reckon with major scientific and technological breakthroughs that might extend people's lifespan far more radically. However, since breakthroughs that could make this happen must now be viewed as a distinct possibility, it would be unwise to rule out a scenario of very substantial life extension. Whether welcomed or dreaded, the consequences would be formidable.

${ }^{23}$ This conjecture is corroborated by the experience of East Asian social policy regimes which have tended to prioritize public education over high spending on/subsidization of medical care and yet achieved excellent aggregate health results [79].
}

universalistic (i.e., global) program were indeed endeavored, then this would raise serious, quite possibly daunting questions of practicability, the answers to which at the present stage are anything but certain - just as the future of world order and the future of work.

\section{Conclusion}

I have sketched three broad areas that are either undergoing fundamental change or whose institutional arrangements will require substantial adjustments to changes taking place in their environments if they are to stay relevant and/or to perform their functions adequately. In all three cases, the respective changes call into question deeply held convictions that have long served as taken-for-granted assumptions for "ordinary" people and social scientists alike: the premises that (1) the modern world is a westcentric world neatly divided up into self-contained, centrally governed national societies, (2) work constitutes the organizing center of the lifecourse, and (3) there is no such thing as a "free lunch", meaning that the means of subsistence/needs satisfaction must be earned, typically through paid labor and payroll deductions for social insurance or its functional equivalents.

As suggested by the Keynes epigraph that opens this article, facing the uncertain that comes with the realization that the future will be different from the present is unpleasant because it can be a source of great anxiety. But clinging to the familiar, while understandable, does not help under conditions of radical change; epistemological conservatism is a poor guide for navigating uncharted terrain.

The concept of global modernity calls into question established modes of thought, conventions and institutions. A paradigm that does this has the capacity to stimulate ideas pointing beyond an unsustainable present. Its strength lies less in devising answers or proposing solutions to known problems than in posing questions that sensitize observers to new, emerging problems for which as yet no clear-cut solutions exist.

Another characteristic of this paradigm is that it prompts analysts to look beyond the geographical confines of the West. Most existing social science is conducted in Western locations and restricts itself to analyzing the Western world. The underlying premise is that to understand the West, one need only know the West, from which most transformative change emanates. This premise made some sense as long as the West was the center of the modern world. But that is no longer the case ([81], see also [20]). In the future, to understand local affairs anywhere in the world will increasingly require adopting a global perspective because these affairs are ever more enmeshed in global flows and networks of activities that affect them. 
Publisher's Note Springer Nature remains neutral with regard to jurisdictional claims in published maps and institutional affiliations.

Open Access This article is distributed under the terms of the Creative Commons Attribution 4.0 International License (http:// creativecommons.org/licenses/by/4.0/), which permits unrestricted use, distribution, and reproduction in any medium, provided you give appropriate credit to the original author(s) and the source, provide a link to the Creative Commons license, and indicate if changes were made.

\section{References}

1. Acharya A (2014) The end of American world order. Polity Press, Cambridge

2. Aeppel T (2016) How the on-demand/gig economy is redefining work. MIT IDE Research Brief 2016(6): 1-3

3. Agraval A, Horton J, Lacetera N, Lyons E (2013) Digitization and the contract labor market: a research agenda. In: Goldfarb A, Greenstein S, Tucker C (eds) Economic analysis of the digital economy. University of Chicago Press, Chicago, pp. 219-250

4. Allegretto S, Doussard M, Graham-Squire D, Jacobs K, Thompson D, Thompson J (2013) Fast food, poverty wages: the public costs of low-wage jobs in the fast-food industry. Labor Center, UC Berkeley

5. Alsweilem KA, Cummine A, Rietveld M, Tweedie K (2015) Sovereign investor models: institutions and policies for managing sovereign wealth. Joint report by the Center for International Development and the Belfer Center for Science and International Affairs. Harvard Kennedy School, Cambridge

6. Anderson B (1983) Imagined communities. Reflections on the origin and spread of nationalism. Verso, London

7. Aneesh A (2006) Virtual migration. The programming of globalization. Duke University Press, Durham

8. Arntz M, Gregory T, Zierahn U (2016) The risk of automation for jobs in OECD countries: a comparative analysis. OECD social, employment and migration working papers no 189 . OECD Publishing, Paris

9. Autor D (2015) Why are there still so many jobs? The history and future of workplace automation. J Econ Perspect 29:3-30

10. Avant DD, Finnmore M, Sell SK (eds) (2010) Who governs the globe? Cambridge University Press, Cambridge

11. Baldwin R (2016) The great convergence: information technology and the new globalization. Harvard University Press, Cambridge

12. Barnett M, Finnmore M (2004) Rules for the world. International organizations in global politics. Cornell University Press, Ithaca

13. Barro RJ, Lee JW (2013) A new data set of educational attainment in the world, 1950-2010. J Dev Econ 104:184-198

14. Barua A (2016) Packing a mightier punch: Asia's economic growh among global markets continues. Deloitte University Press http:// dupress.com/articles/asia-pacific-economic-outlook-q1-2016-asiaeconomic-growth-continues/. Accessed 21 Aug 2017

15. Beitz CR (1999) Political theory and international relations. With a new afterword by the author. Princeton University Press, Princeton

16. Beschorner N, Kuek SC, Narimatsu J (2015) Information \& communication technologies for jobs in the Pacific. Report no. 9621896EAP. World Bank Group, Washington, DC

17. Boli J, Thomas GM (1997) World culture in the world polity: a century of international non-governmental organization. Am Sociol Rev 62:171-190

18. Bornmann L, Mutz R (2015) Growth rates of modern science: a bibliometric analysis based on the number of publications and cited references. J Am Soc Inf Sci Technol 66:2215-2222
19. Brynjolfsson E, McAffe A (2014) The second machine age. Work, progress, and prosperity in a time of brilliant technologies. Norton, New York

20. Buzan B, Lawson G (2015) The global transformation. History, modernity, and the making of international relations. Cambridge University Press, Cambridge

21. Chang JH, Huynh P (2016) Asean in transformation. The future of jobs at risk of automation. International Labour Office, Bureau of Employers' Activities, working paper no 9. International Labour Organization, Geneva

22. Coe N, Yeung HWC (2015) Global production networks. Theorizing economic development in an interconnected world. Oxford University Press, Oxford

23. Daniels N (2008) Just health. Meeting health needs fairly. Cambridge University Press, Cambridge

24. DeMars WE, Dijkzeul D (eds) (2015) The NGO challenge for international relations theory. Routledge, London

25. Dicken P (2015) Global shift. Mapping the changing contours of the world economy, 7th edn. Guildford Press, New York

26. Dobbs R, Madgavkar A, Manyika J, Woetzel J, Bughin J, Labaye E, Kashyap P (2016) Poorer than their parents? Flat or falling incomes in advanced economies, McKinsey Global Institute http:// www.mckinsey.com/global-themes/employment-and-growth/ poorer-than-their-parents-a-new-perspective-on-income-inequality. Accessed 21 Aug 2017

27. Earnest DC (2015) Massively parallel globalization. Explorations in self-organization and world politics. State University of New York Press, Albany

28. Eckes AE Jr (2011) The contemporary global economy. A history since 1980. Wiley-Blackwell, Chichester

29. European Commission (2015) Innovation unit scoreboard 2015. https://www.kowi.de/Portaldata/2/Resources/fp/2015-InnovationUnion-Scoreboard-Report.pdf Accessed 21 Aug 2017

30. Fahy GM, West MD, Coles LS, Harris SB (eds) (2010) The future of ageing. Pathways to human life extension. Springer, Dordrecht

31. Foa RS, Mounk Y (2017) The signs of deconsolidation. J Democr 28(1):5-15

32. Ford M (2015) Rise of the robots. Technology and the threat of a jobless future. Basic Books, New York

33. Frey CB, Osborne MA (2013) The future of employment: how susceptible are jobs to computerisation? Oxford University, Oxford http://www.oxfordmartin.ox.ac.uk/downloads/academic/ The_Future_of_Employment.pdf. Accessed 21 Aug 2017

34. Frey CB, Osborne MA, with contributions from Citi Research (2015) Technology at work. The future of innovation and employment, Oxford Martin School and Citi http://www.oxfordmartin.ox. ac.uk/downloads/reports/Citi_GPS_Technology_Work.pdf. Accessed 21 Aug 2017

35. Gilen M (2012) Affluence and influence. Economic inequality and political power in America. Princeton University Press, Princeton

36. Haggart S, Kaufman RR (2008) Development, democracy, and welfare states: Latin America, East Asia, and Eastern Europe. Princeton University Press, Princeton

37. Hajer MA (2009) Authoritative governance. Policy-making in the age of mediatization. Oxford University Press, Oxford

38. Halliday TC, Carruthers BG (2007) The recursivity of law: global norm making and national lawmaking in the gobalization of corporate insolvency regimes. Am J Sociol 112:1135-1202

39. Holliday I (2000) Productivist welfare capitalism: social policy in East Asia. Polit Stud 48:706-723

40. Hu AGZ, Zhang P, Zhao L (2017) China as number one? Evidence from China's most recent patenting surge. J Dev Econ 124:107-119

41. Jones L (2016) Explaining the failure of the ASEAN economic community: the primacy of domestic political economy. Pac Rev 29(5):647-670. https://doi.org/10.1080/09512748.2015.1022593. 
42. Kaplan J (2015) Humans need not apply: a guide to wealth and work in the age of artificial intelligence. Yale University Press, New Haven

43. Karabarbounis L, Neiman B (2014) The global decline of the labor share. Quarterly Journal of Economics 129(1): 61-103

44. Katz LE, Krueger AB (2016) The rise and nature of alternative work arrangements in the United States, 1995-2015. National Bureau of Economic Research, Cambridge. http://www.nber.org/ papers/w22667.ack. Accessed Sept 2016

45. Keohane RO, Nye JS (2012) Power and interdependence, 4th edn. Longman, Boston

46. Khanna P (2016) Connectography. Mapping the future of global civilization. Random House, New York

47. Kharas H (2010) The emerging middle class in developing countries. OECD development centre working paper no 285. OECD, Paris

48. Kim MMS (2015) Comparative welfare capitalism in East Asia: productivist models of social welfare. Palgrave Macmillan, Basingstoke

49. Koch M (2015) From international to world organizations. In: Holzer B, Kastner F, Werron T (eds) From globalization to world society. Neo-institutional and systems-theoretical perspectives. Routledge, Abingdon, pp 279-300

50. Kohli HS, Sharma A, Sood A (eds) (2011) Asia 2050: realizing the Asian century. SAGE Publications India Pvt Ltd, Manila

51. KPMG (2016) Bots in the back office. The coming wave of digital workers, February 2016. https://assets.kpmg.com/content/dam/ kpmg/pdf/2016/02/bots-in-the-back-office.pdf. Accessed 21 Aug 2017

52. Krasner SD (1999) Sovereignty: organized hypocrisy. Princeton University Press, Princeton

53. Kupchan CA (2012) No one's world. The west, the rising rest, and the coming global turn. Oxford University Press, Oxford

54. Leisering L, Barrientos A (2013) Social citizenship for the global poor? The worldwide spread of social assistance. Int J Soc Welf 22: $50-67$

55. Lleras-Muney A (2005) The relationship between education and adult mortality in the United States. Rev Econ Stud 72:189-221

56. Maddison A (2001) The world economy: a millennial perspective. OECD, Paris

57. Mann M (1986) The sources of power. Vol 1. Cambridge University Press, Cambridge

58. Manyika J (2017) Technology, jobs, and the future of work. McKinsey Global Institute, February 2017, http://www.mckinsey. com/global-themes/employment-and-growth/technology-jobs-andthe-future-of-work. Accessed 21 Aug 2017

59. Masci D (2013) To count our days: the scientific and ethical dimensions of radical life extension. Pew Research Center, 6 August 2013. http://www.pewforum.org/2013/08/06/to-count-our-daysthe-scientific-and-ethical-dimensions-of-radical-life-extension/. Accessed 21 Aug 2017

60. Meyer JW, Boli J, Thomas GM, Ramirez FO (1997) World society and the nation state. Am J Sociol 103:144-182

61. Milanovic B (2016) Global inequality. A new approach for the age of globalization. Harvard University Press, Cambridge

62. National Council of Intelligence (2008) Global trends 2025: a transformed world. Government Printing Office, Washington, DC

63. National Science Board (2016) Science and engineering indicators 2016, https://www.nsf.gov/statistics/2016/nsb20161/\#/.

64. O'Connor S (2015) The human cloud: a new world of work. Financial Times (9 October 2015) https://www.ft.com/content/ a4b6e13e-675e-11e5-97d0-1456a776a4f5. Accessed 21 Aug 2017

65. OECD (2015) Pensions at a glance 2015. OECD and G20 indicators. OECD, Paris
66. Offe C (1992) A non-productivist design for social policies. In: van Parijs P (ed) Arguing for basic income: ethical foundations for a radical reform. Verso, London, pp 61-78

67. Overby S (2012) IT robots may mean the end of offshore outsourcing. CIO Magazine, 26 November 2012, http://www.cio. com/article/2390305/outsourcing/it-robots-may-mean-the-end-ofoffshore-outsourcing.html. Accessed 21 Aug 2017

68. Owen T (2015) Disruptive power. The crisis of the state in the digital age. Oxford University Press, Oxford

69. Peck J (2017) Offshore. Exploring the worlds of global outsourcing. Oxford University Press, Oxford

70. Perlo-Freeman S, Flerant A, Wezeman P (2016) Wezeman S (2016) Trends in world military expenditure, 2015. SIPRI Fact Sheet, April https://www.sipri.org/sites/default/files/EMBARGO\%20FS1604\% 20Milex\%202015.pdf. Accessed 21 Aug 2016

71. Piketty T (2014) Capital in the twenty-first century. Transl by Goldhammer A. Harvard University Press, Cambridge

72. Price DJ d S (1963) Little science, big science. Columbia University Press, New York

73. Rawls J (1971) A theory of justice. Harvard University Press, Cambridge

74. Risse T (2011) Governance in areas of limited statehood. Overview and introduction. In: Risse T (ed) Governance without a state? Policies and politics in areas of limited statehood. Columbia University Press, New York, pp 1-33

75. Sachs JD (2000) Notes on a sociology of economic development. In: Harrison LE, Huntington SP (eds) Culture matters: how values shape human progress. Basic Books, New York, pp 29-43

76. Sassen S (2007) A sociology of globalization. Norton, New York

77. Schmidt VH (2007) One world, one modernity. In: Schmidt VH (ed) Modernity at the beginning of the 21st century. Cambridge scholars publishing, Newcastle, pp 205-228

78. Schmidt VH (2009) Convergence and divergence in societal modernization: global trends, regional variations, and some implications for sustainability. In: Lange H, Meier L (eds) The new middle classes. Globalizing lifestyles, consumerism and environmental concern. Springer, Dordrecht, pp 29-47

79. Schmidt VH (2010) Priorisierung auf der Makroebene. Das Gesundheitswesen im Ensemble sozialpolitischer Leistungsbereiche. Ethik in der Medizin 22:275-288

80. Schmidt VH (2013) Global modernity, world society and global justice: preliminary thoughts. In: Aarni A, Hoeren T, Paulson SL, Schulte M, Wyduckel D (eds) Positivität, Normativität und Institutionalität des Rechts. Duncker \& Humblot, Berlin, pp 73-83

81. Schmidt VH (2014) Global modernity. A conceptual sketch. Palgrave Macmillan, Basingstoke

82. Schmidt VH (2015) Public health ethics. Problems and suggestions. Public Health Ethics 8:18-26

83. Schneiderman D (2008) Constitutionalizing economic globalization. Investment rules and democracy's promise. Cambridge University Press, Cambridge

84. Schwab K (2016) The fourth industrial revolution. World Economic Forum, Cologny

85. Simchi-Levy D (2012) U.S. Re-shoring: a turning point. MIT forum for supply chain innovation 2012 annual re-shoring report, Cambridge

86. Slaughter AM (2004) A new world order. Princeton University Press, Princeton

87. Zhaki A (2016) World's first driverless taxi trial kicks off in Singapore. Straits Times, 26 August 2016. http://www. straitstimes.com/singapore/transport/worlds-first-driverless-taxitrial-kicks-off-in-singapore. Accessed 21 Aug 2017

88. Teubner G (2012) Constitutional fragments: societal constitutionalization and globalization. Oxford University Press, Oxford 
89. UNESCO (2009) Global education digest 2009. Comparing education statistics across the world. The UNESCO Institute for Statistics, Montréal

90. UNESCO (2014) Higher education in Asia: expanding out, expanding up. The UNESCO Institute for Statistics, Montréal

91. UNESCO (2015) UNESCO science report. Towards 2030. UNESCO, Paris

92. Vadera S, Kulshreshtha N (2010) role of SMEs sector in the emerging indian economy. SME World, December 2010. http://www. smeworld.org/story/features-108/role-of-smes-sector-in-theemerging-indian-economy\%20-731.php. Accessed Dec 2010

93. Vaupel JW (2010) Biodemography of human ageing. Nature 464: 536-542
94. Venkatapuram S (2011) Health justice. An argument from the capabilities approach. Polity Press, Cambridge

95. Walter A (2014) Should we be sceptical about prospects for an 'Asian Century'? Aust Econ Rev 47:370-377

96. Westhoff $\mathrm{N}$ (2008) Digital diplomacy: the impact of the internet on international relations. Research report 16. Oxford Internet Institute, Oxford

97. World Bank (2016) Digital dividends. World development report 2016. World Bank, Washington, D.C. http://documents.worldbank. org/curated/en/896971468194972881/pdf/102725-PUBReplacement-PUBLIC.pdf. Accessed 21 Aug 2017 